\title{
Quality of pork for the processing into cooked ham : Predictive value of the measurement of meat pH 24 hours post-mortem
}

\author{
Nicole CARIOU ${ }^{(1)}$, P. JOANNIC ${ }^{(1)}$, M. DUBOIS ${ }^{(2)}$ \\ (1) Association pour le Développement de la Recherche Appliquée aux Industries \\ Agricoles et Alimentaires, 6, rue de l'Université, B.P. 313, 29191 Quimper Cedex \\ (2) Centre Technique de la Salaison, de la Charcuterie et des Conserves de Viandes, \\ E.N.V., 7, avenue du Général-de-Gaulle, 94704 Maisons-Alfort Cedex
}

Given the present cost of the deficient quality of meat, it is necessary and urgent to define methods for controlling the quality of pork compatible with industrial rates of slaughtering and manufacturing of cooked ham (at least 300 pigs per hour).

We tested an industrial method of sorting of meats at the arrival into the processing unit, based on the measurement of the $\mathrm{pH}$ and the appreciation of the colour of the meat, compared with a reference scale ( japanese scale »).

The results showed a relationship between the technological yield (TY) and the $\mathrm{pH}$, described with a good precision by the following equation :

$$
\text { TY }(\text { p. } 100)=101,87-30,826(6-\mathrm{pH})^{2}
$$

Moreover, the sorting based on colour scale is a criterion of interest for a quick detection of PSE meat.

\section{Hygienic and sanitary aspects of pig meat quality}

\section{PINOCHET (1), P. ROBINEAU ${ }^{(2)}$, Elisabeth CHAMPALLE ${ }^{(3)}$, Anne-Marie MATHERAT ${ }^{(4)}$}

(1) Institut Technique du Porc, 35650 Le Rheu

(2) Station de Pathologie Porcine, B.P. 9, 22440 Ploufragan

(3) Centre National de Formation des Techniciens des Services Vétérinaires, rue du Vercors, Z.I. Corbas, Montmartin, 69960 Corbas

(4) Ministère de l'Agriculture, Direction Générale de l'Alimentation,

Service Vétérinaire d'Hygiène Alimentaire, 175, rue du Chevaleret, 75013 Paris

Many parameters are involved in the determination of pig meat microbiologic quality. First, gathering animals of different origins in a single place can lead to intercontamination between batches. Multiple stress undergone by pigs lead to an increased excretion of germs and can possibly be accompanied by slaughter bacteriemy. Bleeding, evisceration and numerous handlings of products during the different stages of processing play a role of primary importance. Equipment can also cause intercontamination, as far as certain parameters are not rigorously monitored (water temperature in scalding tank, plucking and whipping machine, ...) or cleaning is defective.

The design of rooms and equipment, staff and handling hygiene are subjected to preventive rules. Regular control of product salubrity and cold storage chain is performed, as well.

As regards the persistency of various residues (chlorinated hydrocarbons, PCB, chloramphenicol, germ-killers) in pig meat, the French situation is satisfactory. On the contrary, persistency of heavy metals (Cd, Pb) in kidneys of young pigs, which was worrying in 1985 , needs an epidemiological study to be implemented, in order to determine the origin of contamination. 